\title{
STATIC LOAD TESTS, SHORT SERIES INTERPRETATION
}

\author{
ZYGMUNT MEYER \\ West Pomeranian University of Technology in Szczecin, Faculty of Civil Engineering and Architecture, \\ Department of Geotechnics, Szczecin, Poland, e-mail: meyer@zut.edu.pl
}

\begin{abstract}
Statistic load test is the most commonly used method for estimation of the bearing capacity of piles. From the test we obtain the series a values: load-settlement, $Q-S$ curve. In practice, it is extremely difficult to reach the critical load of the pile when the settlement turns out of control. The existing methods that allow bearing capacity to be calculated give the value which is very often $1 / 10$ of the critical load. The question arises if it is possible based upon short series of load, i.e., $0 \div 0.4$ critical load, to predict the critical value of the load, with accuracy which is sufficient for practical calculation. The paper presents a method how to calculate the critical load based upon short series of load in the static load tests.
\end{abstract}

Key words: soil mechanics, static load tests, piles

\section{INTRODUCTION}

Static load test is a widely used method for estimation of bearing capacity of a simple pile [1][5], [8]-[11]. For a sequent load, the settlement is measured so the result of the test is given as a set of values: settlement-load $\left\{s_{i} ; N_{i}\right\}$. In the available literature there are a number of methods and equations which can be used for calculation of bearing capacity of a single pile. The methods do not analyse the critical value of the load, the one for which the settlement turns out of control. So the allowable load which is assumed in engineering practice is $1 / 6 \div 1 / 9$ of the critical load. On the other hand, the assumed small allowable load is the reason of very small settlement of the pile which has nothing to do with the allowable settlement of the foundation. That was the reason for undertaking the following research trying to answer if it is possible to estimate the critical load of a single pile based upon short series of load, i.e., $0 \div 0.4$ of the critical load.

Normally, it is extremely difficult to reach the critical load during static load tests, in order achieve the settlement which turns out of control. If we know the critical load, we can assume then the allowable load putting safety factor or we can assume allowable settlement and from this condition we can calculate the load which implies this settlement.

\section{MATHEMATICAL DESCRIPTION OF THE SETTLEMENT OF A SINGLE PILE}

In literature there are a number of proposals how to draw the curve: settlement-load. But if we use them for further mathematical analysis, i.e., differentiation, integration, boundary values they fail.

So that was the reason that for mathematical description a nonlinear model was taken developed by the author [6], [7]. The applied curve has the following advantages:

- one curve for the whole range of load from zero to the critical one,

- one curve for the whole range of settlement,

- the curve has two asymptotes, one vertical for critical load, and one skew asymptote for load equal to zero (very small load), and it refers to linear Boussinesq theory.

The numerical calculations for the available static load test sets $\left\{s_{i} ; N_{i}\right\}$ indicate that the curve fits very well the measured data. The proposed curve is of the shape

$$
s=C N_{g r} \frac{\left(1-\frac{N}{N_{r}}\right)^{-\kappa}-1}{\kappa}
$$

where:

$s \quad-$ the settlement $[\mathrm{mm}]$; 
$C-$ a constant value representing the aggregated soil reaction modulus $[\mathrm{mm} / \mathrm{kN}]$ (Winkler elastic constant);

$N-$ load applied to the pile head [kN];

$N_{g r}-$ critical load [kN];

$\kappa-$ dimensionless constant.

An example of the graph of the curve (1) is given in Fig. 1.

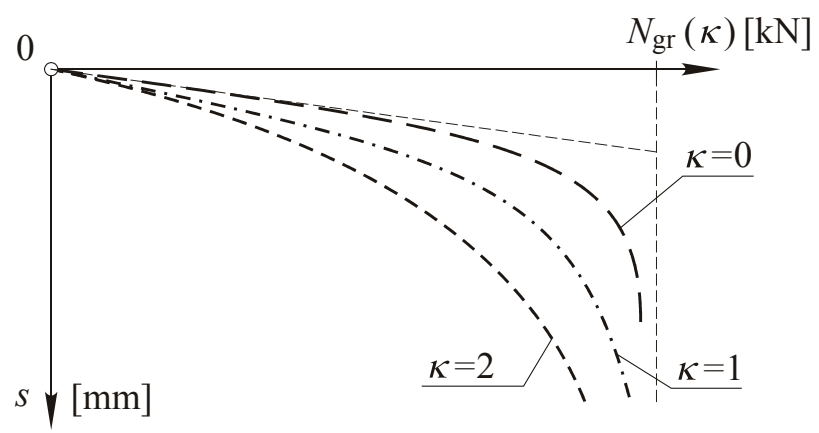

Fig. 1. The graph of the curves $s=s(N ; \kappa)$

From Fig. 1 it appears that for $N \rightarrow 0$ there is:

$$
s=C N
$$

that denotes the skew asymptote. For $N \rightarrow N_{g r}$ we have $s \rightarrow \infty$ and it denotes the vertical asymptote. Formally, the solution that we are looking for relies upon fitting three parameters of the curve: $C ; \kappa$ and $N_{g r}$, to follow the measured values $\left\{s_{i} ; N_{i}\right\}$ obtained during the static load test. From the aforementioned three parameters it seems to be easy to calculate the value $C$, taking the points from the beginning of the curve.

Two others parameters, $\kappa$ and $N_{g r}$, should be estimated using least square method. So, we have

$$
\delta^{2}=\sum\left[s_{i}-s\left(N_{i} ; N_{g r} ; \kappa\right)\right]^{2}=\min .
$$

Numerical calculations based upon available sets $\left\{s_{i} ; N_{i}\right\}$ indicate that the resulting values, $\kappa$ and $N_{g r}$, are very sensitive to the errors of the measured values $s_{i}$ and $N_{i}$. One of the ways to obey this, is to search for an additional relation

$$
N_{g r}=N_{g r}(\kappa) .
$$

\section{ESTIMATION OF THE RELATION$$
N_{g r}=N_{g r}(\kappa)
$$

From the basic equation (1) we can derive the function $N_{g r}=N_{g r}(\kappa)$ using linear regression only for $\kappa=1$ and $\kappa=2$, so we have
- for $\kappa=1$

$$
N_{g r}(1)=\frac{\sum\left(N_{i}^{2}\right)}{\sum\left(N_{i} Y_{1 i}\right)}
$$

where

$$
Y_{1 i}=1-\frac{C N_{i}}{s_{i}},
$$

- for $\kappa=2$

$$
N_{g r}(2)=\frac{\sum\left(N_{i}^{2}\right)}{\sum\left(N_{i} Y_{2 i}\right)}
$$

where

$$
Y_{2 i}=\frac{4\left(\frac{s_{i}}{C N_{i}}-1\right)}{4 \frac{s_{i}}{C N_{i}}-1+\sqrt{8 \frac{s_{i}}{C N_{i}}+1}} .
$$

For other $\kappa$ values for rough estimation we can use linear relation

$$
N_{g r}(\kappa)=N_{g r}(1)\left[2-\frac{N_{g r}(2)}{N_{g r}(1)}+\kappa\left(\frac{N_{g r}(2)}{N_{g r}(1)}-1\right)\right] .
$$

More accurate relation $N_{g r}(\kappa)$ can be obtained by expanding function (1) in Maclaurin series. If we put

$$
\begin{aligned}
& X=\frac{N}{N_{g r}}, \\
& B=\frac{s}{C N},
\end{aligned}
$$

then, for $0<X<0.4$, it allows the following approximation

$$
\text { * } \quad N_{g r}=\frac{N}{6} F_{0}
$$

where

$$
F_{0}=\frac{2 B+1}{B-1}(\kappa+1)+2,
$$

or

$$
* * \quad N_{g r}=\frac{N}{6}\left(\frac{\kappa+2}{Y}\right)
$$

where

$Y=\frac{\sqrt{\left[F_{0}+2(\kappa+2)\right]^{2}-4(\kappa+2)}-\left[F_{0}-2(\kappa+2)\right.}{2\left(2 F_{0}-1\right)}$, 
The comparison of $X=\frac{N}{N_{g r}}$ for different $B$ and $\kappa$

\begin{tabular}{|c|c|c|c|c|c|c|c|c|c|c|c|c|}
\hline \multirow{2}{*}{$\begin{array}{c}\text { No. } \\
\text { Eq. }\end{array}$} & \multicolumn{3}{|c|}{$B=2$} & \multicolumn{3}{c|}{$B=1.5$} & \multicolumn{3}{c|}{$B=1.3$} & \multicolumn{3}{c|}{$B=1.1$} \\
\cline { 2 - 15 } & $\kappa=2$ & $\kappa=1$ & $\kappa=0$ & $\kappa=2$ & $\kappa=1$ & $\kappa=0$ & $\kappa=2$ & $\kappa=1$ & $\kappa=0$ & $\kappa=2$ & $\kappa=1$ & $\kappa=0$ \\
\hline 1 & 2.83 & 2.06 & 1.66 & 4.33 & 3.00 & 1.66 & 6.33 & 4.33 & 2.33 & 16.33 & 11.00 & 5.66 \\
\hline 2 & 2.80 & 1.97 & 1.13 & 4.31 & 2.98 & 1.64 & 6.32 & 4.32 & 2.31 & 16.32 & 10.99 & 5.66 \\
\hline 3 & 2.80 & 1.97 & 1.13 & 4.31 & 2.98 & 1.64 & 6.32 & 4.32 & 2.31 & 16.33 & 10.99 & 5.66 \\
\hline
\end{tabular}

or

$$
* * * \quad N_{g r}=\frac{N}{6}\left[F_{0}-\frac{\kappa+2}{F_{0}+2(\kappa+2)}\right] .
$$

Examples of comparison of the results $N_{g r} / N$ for different values $B$ are given in Table 1 .

Taking equations (12)-(16) it is possible to formulate a general function $N_{g r}(\kappa)$ numerically. And then to use it for statistical calculations. Deeper investigation of the numerical methods is not a matter of the present paper. Furthermore the author focuses on a practical method which can be used in engineering activity dealing with static load tests.

\section{SIMPLIFIED METHOD OF ESTIMATING $N_{g r}$}

A simplified method is based upon replacing original function (1) by approximate function of the type

$$
\ln B=C_{1}+C_{2} \ln X
$$

and noting that

$$
B=\frac{(1-X)^{-\kappa}-1}{\kappa X} .
$$

We can estimate constant values $C_{1}$ and $C_{2}$ as functions of $\kappa$. It gives

$$
C_{1}(\kappa)=0.4062+0.5980 \kappa
$$

and

$$
C_{2}(\kappa)=0.1665+0.2684 \kappa .
$$

The level of this approximation is very high, the correlation coefficient being of order 0.98. Practical application of the procedure is as follows. The calcu- lation of $N_{g r}$ takes two stages (Fig. 2). We assume that we have a set of values $\left\{s_{i} ; N_{i}\right\}$.

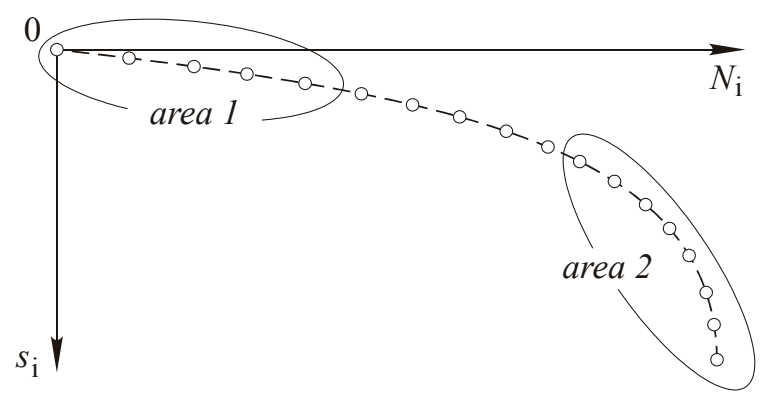

Fig. 2. Division of set $\left\{s_{i} ; N_{i}\right\}$ into two subsets

For the subset area 1, we calculate constant $C$ using the approximation:

$$
s=A_{0} N A_{1}^{N} .
$$

We rearrange this equation into

$$
Y=\frac{S}{N}=A_{0} A_{1}^{N} .
$$

We can apply linear regression using least square method. It can be seen that this approximation gives

$$
C=A_{0} .
$$

For the subset area 2 we use another approximation

$$
s=D_{0} N^{D_{1}} .
$$

Constants, $D_{0}$ and $D_{1}$ come again from linear regression, and as a result we have

$$
B=\frac{s}{C N}=\frac{D_{0}}{C} N^{D_{1}-1}
$$

and further equation (17) takes the form

$$
B=e^{C_{1}(\kappa)}\left(\frac{N}{N_{g r}}\right) C_{2}^{(\kappa)} .
$$


It implies

$$
C_{2}(\kappa)=D_{1}-1
$$

and

$$
N_{g r}=\left(\frac{C}{D_{0}}\right)^{\frac{1}{D_{1}-1}} e^{\frac{C_{1}(\kappa)}{C_{2}(\kappa)}}
$$

Finally, the solution takes the form

$$
N_{g r}=\operatorname{const}\left(\frac{C}{D_{0}}\right)^{\frac{1}{D_{1}-1}},
$$

where

$$
\text { const }=10.9841-1.0567 \cdot D_{1}
$$

and

$$
\kappa=4.924\left(D_{1}-1.1595\right)
$$

\section{EXAMPLES OF CALCULATIONS}

To present the practical usage of the proposed method of simplified estimation of critical load $N_{g r}$ four sets of data coming from the field static load test were chosen.

The tests were made in the surroundings of the town of Szczecin, where the ground is formed by glacial sands from the Odra river valley. The piles were prefabricated concrete elements of size $0.4 \times 0.4$ $\times 12.0 \mathrm{~m}$. The results of the evaluation are given in Table 2. The analysis of equations (29) to (34) indicates that for the rough estimation of the critical load simple formulae can be used

$$
N_{g r}=\left[1933\left(\frac{D_{0}}{C}\right)^{\frac{1}{D_{1}-1}}\right]^{\frac{14}{3}}
$$

The graph of the results of estimation as shown in Table 2 is given in Fig. 3.

Knowing the parameter of equation (1), i.e., $C$; $\kappa$ and $N_{g r}$ we can now calculate the allowable load for the pile $N_{a l}$ based upon the allowed settlement $s_{a l}$. So we have

$$
s_{a l}=C N_{g r} \frac{\left(1-\frac{N_{a l}}{N_{g r}}\right)^{-\kappa}-1}{\kappa},
$$

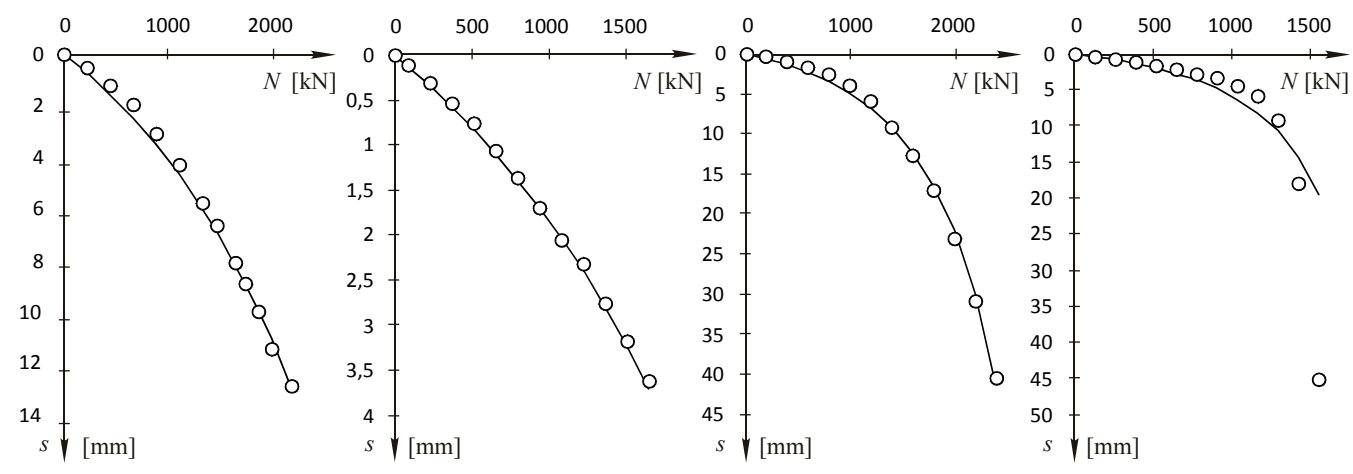

Fig. 3. Graphs of the obtained correlation for the evaluated piles from [7].

(Solid line - calculated, dotted lines - measured)

The results approximation of $N_{g r}$

The value marked $N_{g r}^{*}$ was calculated based upon least square method. Eq. (3)

\begin{tabular}{|c|c|c|c|c|}
\hline No. & 1 & 2 & 3 & 4 \\
\hline$C[\mathrm{~mm} / \mathrm{kN}]$ & 0.002097 & 0.001244 & 0.002606 & 0.001476 \\
\hline$D_{0}$ & 0.0000300 & 0.00017727 & 0.0000006590 & 0.00000002941 \\
\hline$D_{1}$ & 1.690 & 1.338 & 2.277 & 2.700 \\
\hline$\kappa$ & 1.83 & 0.52 & 4.00 & 5.62 \\
\hline$N_{g r}[\mathrm{kN}]$ & 4240 & 2860 & 5880 & 5240 \\
\hline$N_{g r}^{*}[\mathrm{kN}]$ & 4290 & 3100 & 5400 & 4800 \\
\hline
\end{tabular}


where $N_{a l}$ - allowable load [kN]; $s_{a l}$ - allowed settlement of the pile $[\mathrm{mm}]$. And next

$$
N_{a l}=N_{g r}\left[1-\left(\kappa \frac{s_{a l}}{C N_{g r}}+1\right)^{-\frac{1}{\kappa}}\right]
$$

and furthermore, we have the safety factor $S F$

$$
S F=\frac{N_{g r}}{N_{a l}} .
$$

As an example if we take values of the pile 1 from Table 2, it gives for $s_{a l}=3 \mathrm{~cm}, N_{a l}=2800 \mathrm{kN}$. And so, $S F=1.51$.

\section{CONCLUSIONS}

1. A nonlinear model of the load-settlement for static load test results was investigated. It appears that the method can be used for interpretation of the static load test results in the case of short series.

2. As the basic method of estimation of the curve (1) parameters $C, \kappa$ and $N_{g r}$, there remains the least square method applied according to formulae (3).

3. For practical calculations a simplified method can be used. The method consists in replacing the original equation (1) by approximate formula (17). Using this formula makes the calculation simpler when $N_{g r}$ is seen.
4. The problem which remains to be investigated is the meaning of the parameter $\kappa$ in the basic curve (1). It seems to be that it has a physical representation because it corresponds to the ratio of the skin forces to the tow forces of the pile. Another problem is the correlation of the parameters $C$ and $\kappa$ to the parameters of soil forming the ground.

\section{REFERENCES}

[1] Cernica J., Geotechnical Engineering-Foundation Design, J. Wiley \& Sons, 1995.

[2] Cichy L., RyBaK J., Badanie nośności pali prefabrykowanych, Nowoczesne Budownictwo Inżynieryjne, 2009.

[3] GwizdaŁa K., Fundamenty palowe, PWN, Warszawa 2010

[4] Gwizdala K., Kontrola nośności pali i jakości robót polowych, Geoinżynieria i Tunelowanie, 2004, No. 4.

[5] KŁosiŃSKI B., Wspótczesne pale wiercone, Inżynier Budownictwa, 2010.

[6] Meyer Z., Kowalów M., Model krzywej aproksymujacej wyniki testów statycznych pali, Inżynieria Morska i Geotechnika, 2010, No. 3.

[7] Meyer Z., SZMechel G., Metoda interpretacji testów statycznych obciażeń pali prefabrykowanych, 58 Konferencja Naukowa KILiW, PAN, Krynica 2012.

[8] RipPel R., Próbne obciqżenia pali formowanych $w$ gruncie, Inżynier Budownictwa, 2088.

[9] SiEŃKO ZB., KRASIŃSKI A., Pomiar pionowego rozkladu sity w palu podczas testów statycznych, 56 Konferencja Naukowa KILiW, PAN, Krynica 2010.

[10] SIKORA Zb., Sondowanie statyczne, metody i zastosowanie w geoinżynierii, Wydawnictwo Techniczne, Warszawa 2006.

[11] WiŁun Z., Zarys geotechniki, WKiŁ, Warszawa 2000. 